Experimenting with the integrative operational objectives formulated in integrated activities performed in kindergartens from Sălaj county

Clapa (Souca) Valentina, Mușata Bocoș \& Bogdan Neculau 


\title{
Experimenting with the integrative operational objectives formulated in integrated activities performed in kindergartens from Sălaj county
}

\author{
Clapa (Souca) Valentina ${ }^{a^{*}}$, Mușata Bocoș ${ }^{b}$, Bogdan Neculau $^{c}$ \\ ${ }^{a}$ Doctoral School "Educational, Reflection, Development", Babeș-Bolyai University, 7 Sindicatelor Street, Cluj-Napoca, 400029, Romania \\ ${ }^{b}$ Faculty of Psychology and Educational Sciences, Babeș-Bolyai University, 7 Sindicatelor Street, Cluj-Napoca, 400029, Romania \\ ${ }^{c}$ Faculty of Psychology and Educational Sciences, Alexandru Ioan Cuza University of Iași, 3 Toma Cozma Street, Iași, 700554, Romania \\ *Corresponding author: clapa_valentina@yahoo.com
}

\section{Abstract}

Keywords: integrative operational objectives; integrated activities.
The reform that the Romanian school system is currently facing is of utmost importance and is marked by the tendency of the educational institutions to undergo continuous improvement, by the changes in society and the influence of the European school systems.

In our research, we started from the premise that the operationalization of the objectives is an absolutely necessary condition for the educational objectives to be usable in the practice of designing, realizing and evaluating the educational activities. Our proposal is to use the concept of integrative operational objective for the integrated learning contexts specific to the integrated didactic activities.
Die Veränderungen, denen sich das rumänische Schulsystem gegenübersieht, sind heute wichtiger denn je. Sie zeichnen sich durch die Tendenz der lernenden Institutionen aus, sich kontinuierlich zu verbessern, die Veränderungen in der Gesellschaft und die Einflüsse des europäischen Schulsystems.

In unserer Forschung gingen wir davon aus, dass die Operationalisierung von Zielen eine unabdingbare Voraussetzung für die Verwendung von Bildungszielen für die Gestaltung, Durchführung und Bewertung von Bildungsaktivitäten ist. Unser Vorschlag ist, das Konzept des integrativen operativen Ziels für integrierte Lernkontexte zu verwenden, die für integrierte Lehraktivitäten spezifisch sind.

\section{Introduction}

According to Law no. 4.694/2.08.2019 passed by the Ministry of Education and concerning preschool level, starting with year 2019, a new curriculum shall be applied. This one would focus on developing competences that are meant to assure the development of key competences later on in life (Curriculum pentru Educaţia Timpurie, 2019, p. 14).

The Methodical letter for the school year 2019-2020, aside from the new elements added by the curriculum, states that the integrative activities are one of the stability aspects (anchors) that supports an easy integration of the new curriculum (Scrisoarea metodică pentru anul școlar 2019-2020, Nr. 38407/ 01.10.2019, p. 4).

This research continues the approach undertaken between 2013 to 2017 that was directed towards applying and explaining the integrative operational objectives in the integrated activities that took place in the kindergartens from Sălaj County.

All the studies and interviews conducted at school inspections in that period led to the conclusion that teachers needed to attend training courses. These trainings were meant to clarify how to design and conduct integrated activities and how exactly to formulate integrative operational objectives (i.o.o.). The integrative operational objective (of the integrated didactic activity) represents a type of operational objective formulated so as to explain the level/ area of integration of the content which is to be inserted in certain integrated didactic activities which are supposed to be transmitted, modeled and assimilated (Bocoş, (coord.), Răduţ-Taciu, Stan, 2018).

Therefore, in November-December 2017 the training course "Innovative approaches in the specific didactics of primary and pre-school education" was organized. A 
number of 80 educators benefited from a training session provided by the Babeș-Bolyai University Cluj-Napoca Năsăud Extension, aimed at formulating the operational objectives, to which we added explanations regarding the formulation of the integrative operational objectives. In order to identify the impact that the course had on the teachers' ability to formulate integrative operational objectives, during the period January-May 2018 school inspections and demonstrative activities were organized and methodological-scientific reports were written in each methodical center.

\section{Methodology}

In January and May 2018, the coordinators of methodical centres in Sălaj were asked to collect the activity projects and the methodological-scientific reports written by the teachers who held activities during the meetings organized in the first and in the second semester of the 2017-2018 school year. Afterwards, the documents were analysed and for a number of 81 didactic projects and reports were identified the strengths and the areas of improvement. Main concerns were:

- formulation of operational objectives;

- formulating the integrating operational objective;

- the teaching methods - modern vs. traditional;

- the didactic means used;

- the weight of the frontal activity vs. group/ individual activity;

- contents - informative vs. formative;

- types of evaluation;

- the scenario of the integrated activity;

- correlations between the components of the teaching act, strategies and evaluation;

- the methodological-scientific reports (the quality of the information, their relevance to the topic, the methodical suggestions, bibliographic references, language used, terminology mastery, the realism of the approaches, the degree of applicability, the degree of originality).

During the same period, January-May 2018, semistructured interviews were conducted with 21 of the teachers who organised school inspections in order to obtain their teaching qualifications from which:
- final grade - 5 teachers;

- current / special grade II - 8 teachers;

- current / special grade I - 8 teachers.

\section{Results}

Following the analysis of the activity projects and the methodological-scientific reports, it was found that:

- the operational objectives were, in general, clear and relevant. Still, they were not always formulated according to Mager's Technique (Bocoş, Jucan, 2019);

- and sometimes the level of performance was omitted;

- there were also projects in which many objectives and complex formulas were set and thus it was difficult to follow whether the objective was achieved for each child or not;

- in the combined groups the objectives rarely reflected the differentiated approach according to the age of the children;

- in most integrated activity projects, where the integrating operational objective was formulated, an effort was made to reveal, by formulation, the way of integrating the contents from two or more disciplines / experiential fields (58 projects $71.60 \%$;

- there are numerous projects in which, starting from the formulation of the i.o.o. and of the didactic scenario, it appears that the training/ teaching-learning sequences of the contents from two or more disciplines/ experiential fields were made consecutively, which suggests that either the methodology of formulating the i.o.o. was not understood, or the activities were carried out, practically, in relation to the disciplines and switching from one activity to the other was made through a transition stage (32 projects - 39.50\%);

- there were also projects carried out at disciplines where implicitly there was no i.o.o. formulated (23 projects from the rural area $-28.39 \%$ ), which may suggest that, if at the moment of inspection (methodical visit) the integrated activities were not designed and carried out by the educators, then, probably they were not at all designed and developed in the day by day activity of teachers in the rural area; 
- in general, both the contents and the forms of evaluation were in accordance with the operational objectives set (including i.o.o.);

- modern, interactive methods were used in most projects for integrated activities;

- the didactic means were rich and different, they followed the characteristics of a valuable didactic material, both from an aesthetic point of view and from the perspective of their usefulness and most were made by the teachers' themselves;

- all types of class organization were present, but in some cases, the frontal activity predominated when two activities for experiential domains were integrated (ADE). The activities in small and individual groups were more common in the full day integrated activities;

- for consolidation and evaluation activities, the informative aspect prevailed in the presentation of the contents;

- the types of evaluation were documented in reports, but it is difficult to appreciate based on such documents how much of the child's progress was taken into account;

- the formative evaluation was present (behavioral observation, oral questioning, positive feedback);

- the evaluation referred to the proposed objectives (including i.o.o.), and the children were also involved in the evaluation process (selfevaluation was sometimes present in the design);

- the contents transmitted were accessible so as to allow the children to understand quite abstract notions such as: the beauty in nature, the beauty in art, the harmony, the rhythm, etc.;

- the activity scenario existed in many of the projects and the description clearly showed the flow of the didactic events (integrated activity projects were presented without a didactic scenario such as the discipline-specific projects that did not require a didactic scenario);

- where elaborated, the activity scenarios were well designed, presented in detail, offering a good overview of the didactic approach;

- in the activity projects the didactic events were recorded in the corresponding section, the detail of the activity, for each moment, was brief, but relevant;
- the methodological-scientific reports comprised theoretical aspects on topics under debate, as well as ways of carrying out the activities, but the examples of good practice from personal experience were scarcely reflected in the documents;

- there were reports that had used the same bibliographic sources, but the author's personal contribution would bring extra originality if personal experience in relation to the group of children in the kindergarten was promoted;

- the information in the reports was relevant to the topic, there were also methodological suggestions and bibliographic references; the language used was, in general, colloquial, the degree of mastery of the terminology differed from case to case;

- two of the reports received in a methodical centre were copied largely from the Internet, being almost identical in content to the source text.

Following the analysis of the school documents and the interviews conducted with a number of 21 teachers that have been evaluated, it was found that:

- they have designed and carried out integrated activities, on average 1-2 per week (85.72\%), respectively 3-4 (14.28\%);

- $89.25 \%$ integrate disciplines from experiential fields (ADE - activities for experiential domains);

- $61 \%$ of the respondents identify a series of benefits of conducting formulation and follow-up of the i.o.o., both in relation to the integration of the contents, as well as to the evaluation and elaboration of the didactic tasks;

- $71.42 \%$ of the educators appreciate that i.o.o. should be formulated for all / most of the integrated activities, $19 \%$ - do not express an opinion or consider that the impact of its formulation on the didactic design should be investigated, and $9.52 \%$ consider that it should not be used;

- $\quad 28.57 \%$ of the respondents reported difficulties facing the formulation of i.o.o., $4.76 \%$ considered that the thinking time to formulate an i.o.o. is quite long, and $14.28 \%$ state that they cannot formulate it for all integrated activities. 


\section{Conclusions}

Following the analysis of the activity projects and the methodological-scientific reports, one considers that it is necessary to take some improvement measures:

- the elaboration of a methodical letter, at county / country level, specifying aspects related to the formulation of objectives (a list of verbs that target observable behaviors), the stages of each activity, the correct identification of the types of evaluation, the way of recording sequentially the teaching strategies, with examples of activity projects (integrated activities);

- practice within the methodical meetings the formulation of the operational objectives by using Mager's Technique (M. Bocoş, D. Jucan, 2019) and the formulation of the integrative operational objectives;

- for the correct elaboration of the integrating operational objective, it would be useful to present as many examples as possible of the formulation of the integrative objective, reflecting combinations of objectives from different disciplines/ domains of experience and to promote them among teachers;

- encouraging and appreciating the use of modern methods/ the recommendation to use in designing activities at least one interactive method on each integrated activity, along with the traditional ones;

- to detail, in the integrated activity project, each stage of the activity, not just the simple review of the contents related to it, because such an activity project does not clearly reflect what the proponent wants to achieve and the way he/ she does it;

- to design the didactic scenario for each type of integrated activity;

- the methodological-scientific reports should reflect how the teacher approached the proposed topic in practice;

- the participating teachers, in their interventions at the pedagogical/ methodical meeting, shall discuss the topic not only regarding the demonstrative activity pursued/ the methodological-scientific report audited, but also to bring to the attention of the auditor aspects of personal experience in the class (in the individual notebook shall be found previously studied topics discussed within the methodological meetings and the pedagogical gathering);

- the study by the educators of the guides that offer suggestions for the elaboration of the projects of integrated activities and more concern for both the form and the content of the documents (some projects contain spelling mistakes, there is a lack of interest for complying with the writing standards, elliptical contents, lack of coherence and superficiality in the presentation of the teaching approach).

Following the interviews with the teachers who have organized school inspections, some needs arise:

- organize meetings with mentors to explain and practice writing i.o.o.;

- stimulating the teachers to study and constantly practice formulating integrative operational objectives.

It can be argued that most of the participants in the study appreciated the usefulness of formulating and pursuing integrated operational objectives for integrated activities, but there were educators who found it difficult to formulate and continue to seek advice and guidance, both for designing integrated activities and for formulating operational integrator objectives.

\section{Authors note:}

The authors have equal contributions to this article.

Clapa (married Souca) Valentina-Lucia is currently a school inspector for Early Education at the School Inspectorate of Sălaj County and a Doctoral Student at Babeș-Bolyai University of Cluj-Napoca. Her areas of research concern the identification of innovative ways of formulating operational objectives specific to the integrated activities. She is also interested in finding the most effective teaching practices that could be used successfully in the educational process.

Mușata Bocoş is University Professor and Ph.D. Coordinator at the Faculty of Psychology and Sciences of 
Education (Babeș-Bolyai University, Cluj-Napoca, Romania). She has obtained a Ph.D. in Educational Sciences in 1997 at Babeș-Bolyai University. Her research interests are reflected in a series of studies and articles published in important national and international journals. Her teaching activity covers several domains such as the theory and methodology of curriculum, general didactics, and educational research.

Bogdan Neculau is Ph.D. Lecturer at the Teachers' Training Department of the Psychology and Education Sciences, "Alexandru Ioan Cuza" University of Iasi. He graduated at the same university, both The Faculty of Theology and the Faculty of Psychology and Education Sciences and he obtained a Ph.D. in Education Sciences (2007). He teaches courses on Introduction in Pedagogy, Curriculum Theory and Methodology, Teaching Theory and Methodology, Evaluation Theory and Methodology, Communication Pedagogy, Educational Management to the students who would like to pursue a career in teaching. $\mathrm{He}$ has published a series of articles and studies in the area of General Didactics, Christian Pedagogy and Teacher Training. He is a reviewer of scientific committee of numerous conferences and scientific events that have been organized within the university and pre-university environment.

\section{References}

Bocoş, M.-D. (coord.), Răduţ-Taciu, R., Stan, C. (2018). Dicţionar Praxiologic de Pedagogie. Volumul IV: M-O. Pitești: Editura Cartea Românească Educaţional.

Bocoş, M., Jucan, D. (2019). Fundamentele pedagogiei. Teoria şi metodologia curriculumului. Repere şi instrumente didactice pentru formarea profesorilor, ediţia a IV-a, revizuită. Pitești: Editura Paralela 45.

*** Ministerul Educației Naționale. (2019). Curriculum pentru educația timpurie. Available at: https://www.edu.ro/sites/default/files/Curriculum\%20ET_20 19 aug.pdf (accessed at 30.09.2019).

*** Scrisoarea metodică pentru anul școlar 2019-2020, Nr. 38407/ 01.10.2019, p. 4. Available at: https://www.isjsalaj.ro/discipline/invatamant_prescolar/Scris oare_metodica_2019.pdf (accessed at 30.09.2019). 